\title{
An exploration of the complex biogeographical history of the Neotropical banner-wing damselflies (Odonata: Polythoridae)
}

Melissa Sánchez-Herrera ${ }^{1,2^{*}}$ (D), Christopher D. Beatty ${ }^{3}$, Renato Nunes ${ }^{2,4}$, Camilo Salazar ${ }^{1}$ and Jessica L. Ware , $^{2,5}$

\begin{abstract}
Background: The New World Tropics has experienced a dynamic landscape across evolutionary history and harbors a high diversity of flora and fauna. While there are some studies addressing diversification in Neotropical vertebrates and plants, there is still a lack of knowledge in arthropods. Here we examine temporal and spatial diversification patterns in the damselfly family Polythoridae, which comprises seven genera with a total of 58 species distributed across much of Central and South America.

Results: Our time-calibrated phylogeny for 48 species suggests that this family radiated during the late Eocene ( $33 \mathrm{Ma}$ ), diversifying during the Miocene. As with other neotropical groups, the Most Recent Common Ancestor (MRCA) of most of the Polythoridae genera has a primary origin in the Northern Andes though the MRCA of at least one genus may have appeared in the Amazon Basin. Our molecular clock suggests correlations with some major geographical events, and our biogeographical modeling (with BioGeoBEARS and RASP) found a significant influence of the formation of the Pebas and Acre systems on the early diversification of these damselflies, though evidence for the influence of the rise of the different Andean ranges was mixed. Diversification rates have been uniform in all genera except one-Polythore-where a significant increase in the late Pliocene ( 3 mya) may have been influenced by recent Andean uplift.
\end{abstract}

Conclusion: The biogeographical models implemented here suggest that the Pebas and Acre Systems were significant geological events associated with the diversification of this damselfly family; while diversification in the tree shows some correlation with mountain building events, it is possible that other abiotic and biotic changes during our study period have influenced diversification as well. The high diversification rate observed in Polythore could be explained by the late uplift of the Northern Andes. However, it is possible that other intrinsic factors like sexual and natural selection acting on color patterns could be involved in the diversification of this genus.

Keywords: Damselfly, Neotropical region, Zygoptera, Ancestral areas, Andean uplift, Marine incursions, Central America seaway, Odonata

\footnotetext{
* Correspondence: melsanc@gmail.com; melissa.sanchezh@urosario.edu.co

'Department of Biology, Faculty of Natural Sciences, Universidad del Rosario, Bogota, DC, Colombia

${ }^{2}$ Federated Department of Biological Sciences. Rutgers, The State University of New Jersey, Newark, NJ, USA

Full list of author information is available at the end of the article
}

(c) The Author(s). 2020 Open Access This article is licensed under a Creative Commons Attribution 4.0 International License, which permits use, sharing, adaptation, distribution and reproduction in any medium or format, as long as you give appropriate credit to the original author(s) and the source, provide a link to the Creative Commons licence, and indicate if changes were made. The images or other third party material in this article are included in the article's Creative Commons licence, unless indicated otherwise in a credit line to the material. If material is not included in the article's Creative Commons licence and your intended use is not permitted by statutory regulation or exceeds the permitted use, you will need to obtain permission directly from the copyright holder. To view a copy of this licence, visit http://creativecommons.org/licenses/by/4.0/ The Creative Commons Public Domain Dedication waiver (http://creativecommons.org/publicdomain/zero/1.0/) applies to the data made available in this article, unless otherwise stated in a credit line to the data. 


\section{Background}

The New World tropics is a region of amazingly high diversity in a variety of plants and animals, and has a complex history [1]. Shifting continents, multiple instances of mountain building, rivers that change their course, and the expansion and retreat of both freshwater and marine habitats all come together to make a complicated and dynamic foundation on which biological diversity has developed over the last 50 million years (Ma). These include the uplift of the different regions of the Andes, as well as the Venezuelan Highlands, the formation of the extensive Amazonian flood basin in the Miocene (Pre-Pebas, Pebas and Acre), the further development of the Amazon and Orinoco drainages, the dry/wet climate cycles of the Pliocene/Pleistocene, and the formation of the Panamanian Land Bridge between the TumbesChocó-Magdalena regions and Central America [2-4].

In a number of groups (tropical frogs [5, 6], butterflies [7, 8], lupines [9], birds [10]) this changing geography has driven substantial-sometimes rapid-diversification, but not always in the same way. The diversification driven by these geographic changes often promotes niche diversification, with species taking advantage of the distinct ecological niches found in each local environment. This leads to adaptive speciation [11], further increasing diversity beyond the form of the landscape. Here we investigate the origins of diversity in the banner-winged damselflies (Odonata: Zygoptera: Polythoridae), a group that is distributed across much of Central and South America.

Polythoridae comprises 58 species across seven genera (Chalcopteryx Selys, Chalcothore De Marmels, Cora Selys, Euthore Selys, Miocora Calvert, Polythore Calvert and Stenocora Kennedy) that differ markedly in their distribution: some are found widely across the continent, while others are limited to a single region. While damselflies as a group are generalist predators in both their larval and adult forms, the types of aquatic habitats in which their larvae are found vary, with some species using lakes and ponds, while others inhabit streams and rivers. The larvae of Polythoridae prefer moving water; most species are found in small, fast-flowing streams in mountain regions, though some additionally exist within slow streams in the Amazon Basin [12]. These species display a diverse range of colors and patterns on both the wing and body within and among genera; previous work by Sánchez Herrera et al. $[13,14]$ has shown that for some genera, wing colors may be polymorphic, raising the question of what factors drive this color diversity.

We tested hypotheses concerning the diversity within Polythoridae, investigating the influence of geological events in shaping the distribution of the members of this family. Using relaxed-clock molecular methods we estimate divergence times within and among the genera of this family. We also investigate their biogeographical patterns of diversification in relation to the mountain building events of the Andes, as well as the extent of marine and freshwater environment incursions in different periods that might have influenced distribution and speciation in these genera. Specifically, we made the following predictions: (1) We predict that the Andes uplift was a major driver of speciation in the family Polythoridae. Therefore, we also predict (2) that there were multiple interchanges between Neotropical regions, particularly from the Andean regions to the other biogeographical regions of Central and South America, for the different genera within Polythoridae. Finally (3) we predict that the family Polythoridae (or genera within) has experienced higher rates of diversification through recent evolutionary time. Overall, this work represents a continental-scale biogeographical analysis of a neotropical family of damselflies. With their reliance on aquatic habitats, damselflies are likely to respond very differently to the landscape than plants, terrestrial vertebrates or insects; our analyses allow us to consider the formation of diversity in the modern Neotropics through an unexplored arthropod perspective.

\section{Results}

\section{Phylogeny and time divergence estimation}

Our IQTree ML phylogenetic reconstruction, as well as our BEAST time calibrated tree, were completely concordant with the clades previously recovered by Sánchez Herrera et al. [13] (Fig. 1, Fig. S1), though our current dataset includes 12 additional species. The family Polythoridae separated from our Outgroups 46 Ma (49-42 Ma 95\% HPD [High Probability Density intervals], pp. [posterior probability] $=0.9125$ ). Our time divergence reconstruction suggests that the MRCA (Most Recent Common Ancestor) of the family Polythoridae diverged $\sim 33 \mathrm{Ma}(37-29 \mathrm{Ma} 95 \% \mathrm{HPD}, \mathrm{pp} .=1)$ during the late Oligocene and early Miocene boundary. The Chalcopteryx -Chalcothore crown clade itself began to diversify later during the early Miocene $\sim 17.13 \mathrm{Ma}$ (24.17-9.6 Ma 95\% HPD, pp. =1), while the crown group of all of the other Polythoridae genera (Cora s.s., Miocora, Euthore and Polythore clades) began to diversify $\sim 27 \mathrm{Ma}$ (23.10-31.20 Ma 95\% HPD, pp.=1) during the late Oligocene. Chalcothore separated from Chalcopteryx 17.13 Ma (24.17-9.6 Ma 95\% HPD, pp. =1) around the mid Miocene, however the crown group of Chalcopteryx only diversified during the late Miocene $\sim 10.5 \mathrm{Ma}$ (13.8-6.24 Ma 95\% HPD, pp. =0.8). The MRCA of the Cora s.s clade separates from all the other taxa $\sim 27 \mathrm{Ma}$, however its crown group of Cora s.s. appears $\sim 15.8 \mathrm{Ma}$ $(19.8-12.13 \mathrm{Ma} 95 \%$ HPD, pp. $=1)$ around the end of the early Miocene (Fig. 1). The crown group of the Miocora clade appears 10.2 Ma (13.9-6.62 Ma 95\% HPD, 


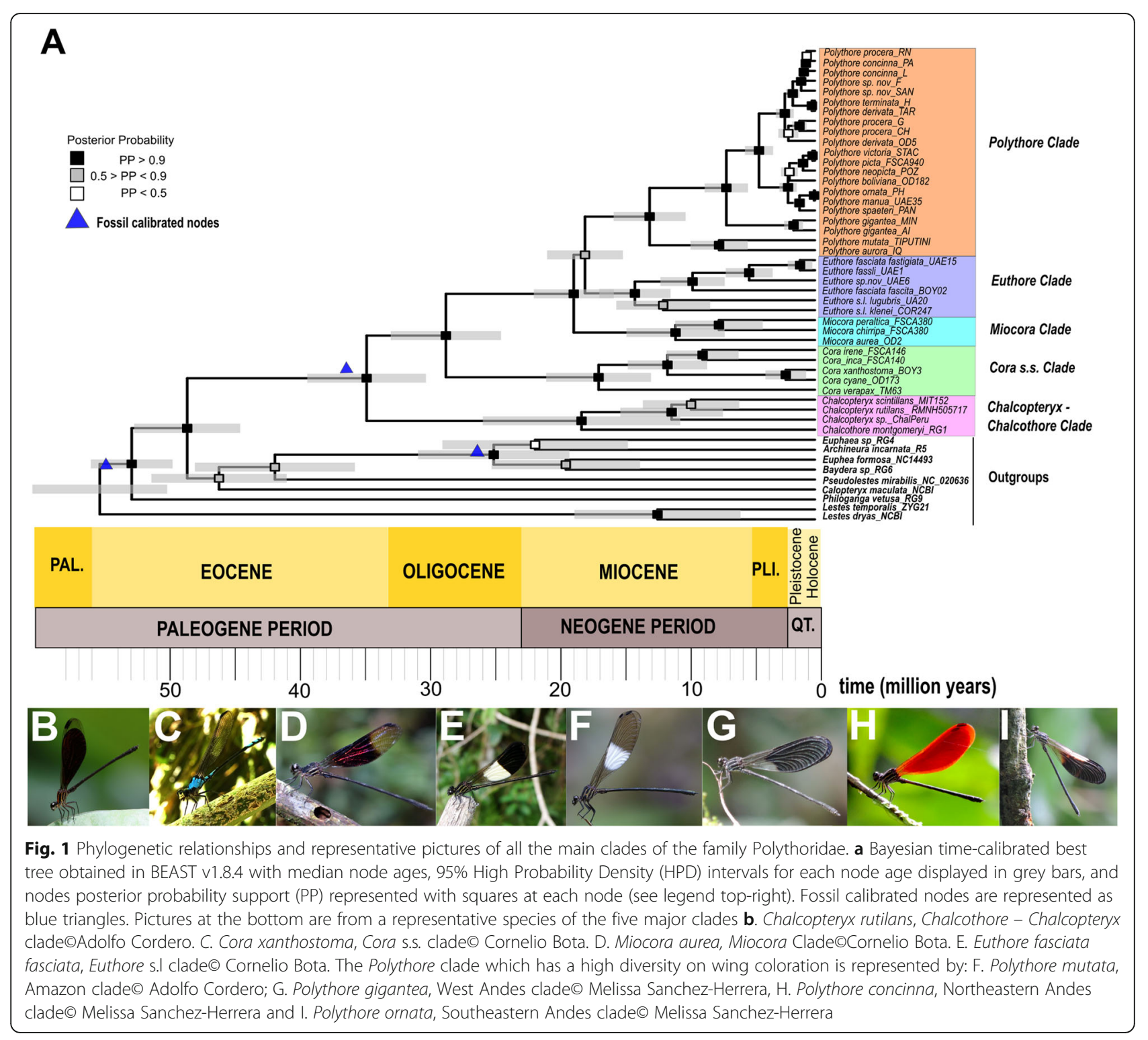

pp. =1), a few million years after Cora s.s during the mid-Miocene, although the MRCA of Miocora (separate from the Euthore and Polythore clade) appears $\sim 17.7 \mathrm{Ma}$ (20.7-14.8 Ma 95\% HPD, pp. =1) during the early Miocene epochs (Fig. 1). The two sister clades of Euthore and Polythore diverged from each other around the same epoch as Miocora, 16.9 Ma (19.4-13.8 Ma 95\% HPD, pp. $=0.65)$, but both form crown groups concurrently around the mid Miocene, though Euthore estimates are slightly older than those for Polythore (Fig. 1). Euthore crown group diversified $\sim 13.2 \mathrm{Ma}(15.8-10.6 \mathrm{Ma} 95 \%$ HPD, pp. =1) while Polythore seems to be $\sim 12.1 \mathrm{Ma}$ (14.8-9.55 Ma 95\% HPD, pp. =1). Within the Euthore clade we recovered two sister clades: Euthore sensu stricto (e.i. E. fasciata fasciata, E. fasciata fastigiata, E. fassli, E. sp. nov), and what used to be part of Cora (i.e.
E. lugubris and E. klenei). Within the Euthore clade the divergence times recovered suggest that Euthore sensu stricto, $\sim 8.9 \mathrm{Ma}(11.3-6.6 \mathrm{Ma}, 95 \% \mathrm{HPD} ; \mathrm{pp} .=0.8)$, is younger that the previous classified Cora species within this clade, 11.13 Ma (13.45-6.6 Ma, 95\% HPD; pp. = 0.7).

In the highly speciose Polythore clade we recovered the divergence times for all the previous geographical clades reported in Sanchez Herrera et al [13] (Fig. 1, Fig. S1). The crown group of the Amazonian clade appeared 7.03 Ma (7.33-3.04 Ma 95\% HPD, pp. =1), while the Andean clade was $\sim 6.5 \mathrm{Ma}(6.67-2.89 \mathrm{Ma} 95 \% \mathrm{HPD}, \mathrm{pp} .=$ $1)$. Within the Andean clade, the crown groups of the West and East Andean clades appeared 1.56 Ma (6.553.42 Ma 95\% HPD, pp. =1) and 4.1 Ma (7.93-3.5 Ma 95\% HPD, pp. $=1)$, respectively. Moreover, estimates for the North ( 2.28 Ma, 2.8-0.99 Ma 95\% HPD, pp. = 1) and 
South Eastern ( 1.96 Ma, 3.17-1.19 Ma 95\% HPD, pp. = 1 ) crown groups suggest they appeared around the Pliocene - Pleistocene epochs (Fig. 1).

\section{Biogeographical reconstruction}

We designed and tested five different scenarios-Control (S0), Pebas \& Acre Systems (P\&AS, S1), ANDES Old uplift (ANDES O, S2), ANDES young uplift (Andes Y, S3), Pebas \& Old Andes (P\&OA, S4) and Pebas \& Young Andes (P\&YA, S5)-to reconstruct the Ancestral Areas through multiple biogeographical models (e.g. DIVA, DEC or BayAreaLike) for the Polythoridae. The designated areas include; (A) Central America, (B) TumbesChoco-Magdalena, (C) North Western Andes, (D) North Eastern Andes, (E) Venezuela Highlands, (F) Central Andes, (G) Amazon Basin, (H) Guiana Shield, and (I) Brazilian Shield. For the control scenario, we tested if the phylogenetic relationships (i.e. cladogram) alone will recover the Ancestral Areas without imposing any restrictions (e.g. dispersal and adjacency) of the geological events including the Andes uplift and Marine incursions of South America (see details in Fig. 2). We selected the best biogeographical models for all scenarios (S0, S1, S2, etc.) using the AICc criteria from BioGeoBEARS. The lowest AICc value for all the scenarios tested was DEC or DEC + J (Table S2). However, following the Ree and Sanmartín [15] critique of the DEC + J model, we reconstructed the DEC and next best fitted biogeographic model based on the AICc for each scenario (Table 2). For all the scenarios $(\mathrm{S} 0-\mathrm{S} 5)$ we reconstructed the ancestral areas using the best model selected-DEC and S-DECusing BioGeoBEARS and RASP software, respectively. However, for the second best model for both the Control (S0) and the P\&AS model (S1), we reconstructed the areas using the DIVALIKE and S-DIVA models, while for all the other scenarios (S2, S3, S4 and S5), the BayAreaLike model was reconstructed in BioGeoBEARS. The lowest AICc values across all the scenarios were for the control S0, which was followed very closely by the P\&AS (S1) (Table 1). The next lowest AICc values were the P\&YA (S5) and the Young ANDES (S3), while the others (S2 and S4) seem not to fit the diversification model. However, there were no major differences in the reconstructed ancestral areas (Table S2) when comparing among all five models in both BioGeoBEARS and RASP. To simplify, here we will describe the most likely ancestral areas estimated for the four scenarios with the lowest AICc values (Fig. 3). All reconstructions became problematic at the deeper nodes, so the likelihood values supporting the areas are lower than $70 \%$ in nodes 39, 42 and 47 (Fig. 3), suggesting uncertainty in the ancestral areas for the MRCA for the family Polythoridae (node 39), for the clade that includes Cora s.s, Miocora, Euthore and Polythore (node 42), and also for the MRCA of the Miocora, Euthore and Polythore clades (node 47). For the MRCA (node 48) of Euthore and Polythore, the Northwest Andes (C) is the most commonly predicted ancestral area for all scenarios (Fig. 3). The MRCA (node 49) for the crown group of Euthore is consistently found in the Northwest Andes (C) in all scenarios (Fig. 3). The MRCA (node 43) for the crown group of Cora s.s. has an ancestral area in the Northwest Andes (C), with the exception of S3, where in addition the Central Andes (F) and Venezuelan highlands (E) are supported (Fig. 3). The MRCA (node 74) for the Miocora crown group is found in the Tumbes-ChocóMagdalena Valley (B) and the Northwest Andes (C). The youngest MRCA (node 40) of the Chalcopteryx-Chalcothore crown group showed as more plausible areas the Amazon Basin (G), and the Venezuelan Highlands (E); S1 also supports the Brazilian Shield (I) (Fig. 3). Finally, the MRCA (node 54) of the Polythore crown group is the only group that shows different ancestral areas depending on the scenarios: for S0 the Northwest Andes (C) and the Amazon Basin (G), for S1 the Northwest Andes (C), the Amazon Basin (G) and the Central Andes (F), for S3 only the Amazon Basin (G), and for S5 the Central Andes (F) and the Amazon basin (G) (Fig. 3, Table S2). It is interesting to note that the different scenarios (S0-S5) within our BioGeoBEARS and RASP analyses did not produce fundamentally different ancestral areas; inclusion of the formation of the Pebas and Acre wetlands systems, as well as mountain building events, did not alter our results in comparison with a simple control scenario that allowed free dispersal between adjoining regions at different periods of geological time (Fig. 2). Our best selected S-DEC model implemented in RASP for the Pebas and Acre Systems (S1) scenario suggests several dispersal (27), and vicariance (9) events within the different genera of Polythoridae (Fig. S3); many of these involve movement within and between the different ranges of the Andes, as well as movement into the Amazon, Guiana Shield, Venezuela Highlands, the Tumbes-Chocó-Magdalena Valley, and Central America.

\section{Diversification analyses}

To investigate the patterns of diversification and extinction rate variation through time and across lineages, we chose RevBayes $[16,17]$ to test the best diversification models and rate shifts, due to the high uncertainty associated with phylogenetic tree estimation. The Episodic Birth-Death with multiple time periods was the best model explaining the diversification pattern in this group of damselflies (Table S4). The estimated net diversification $(\lambda-\mu)$ and speciation $(\lambda)$ rates show an increase, however the relative extinction $(\lambda / \mu)$ and extinction $(\mu)$ rates pattern seem to behave constantly through time (see Fig. S5). The Branch specific model detected a shift in diversification $(\lambda-\mu)$ rate corresponding to the Andean 


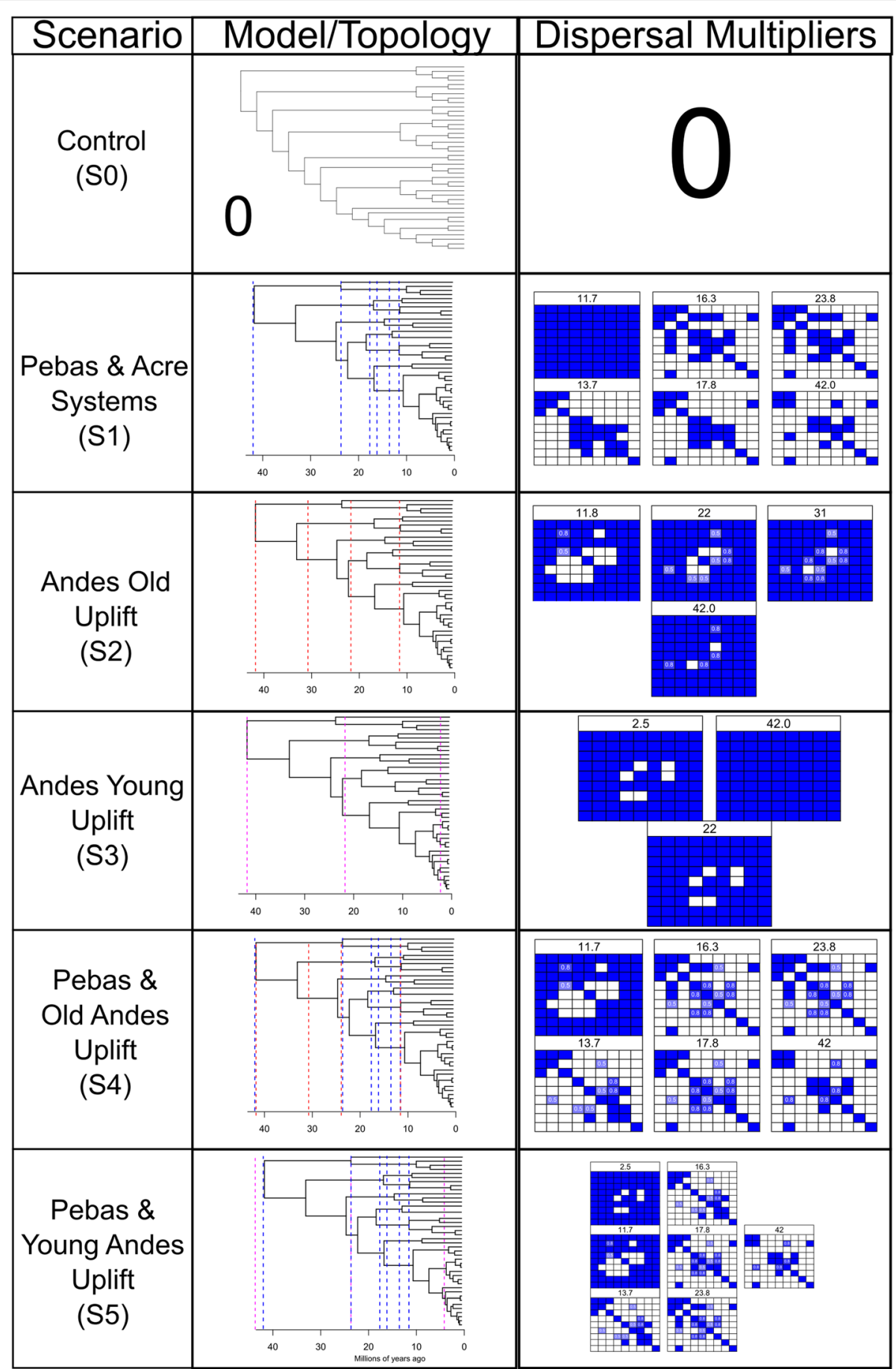

Fig. 2 Designed Biogeographical Scenarios for the Ancestral Areas Reconstructions. All the five scenarios (S0-S5) tested in our biogeographical analyses using BioGeoBEARS accounting for the major geological events in South America. For each scenario, we show the tree topology model, time periods (i.e Millions of Years Ago) and dispersal multiplier matrices across all tested nine areas. The blue (1) to white (0) gradient represents the probability of dispersion across the areas. The Pebas and Acre Systems scenarios were designed using a combination of Hoorn et al. 2010 and Jaramillo et al. 2017, while for all Andes scenarios we used a combination of Hoorn et al. 2010 supplementary material and Gregory-Wodzicki 2000 
Table 1 BioGeoBEARS model selection AICc values for each of the scenarios tested. The lowest AICc values are highlighted in black, and the second lowest in light grey

\begin{tabular}{|c|c|c|c|c|c|c|c|c|}
\hline Scenario & Model & LnL & numparams & d & e & $\mathbf{j}$ & AICc & AICc_wt \\
\hline \multirow{6}{*}{ Control (S0) } & $\mathrm{DEC}$ & -95.17 & 2 & 0.0068 & $1.00 \mathrm{E}-12$ & 0 & 194.7 & 0.27 \\
\hline & $\mathrm{DEC}+\mathrm{J}$ & -93.04 & 3 & 0.0056 & $1.00 \mathrm{E}-12$ & 0.012 & 192.8 & 0.7 \\
\hline & DIVALIKE & -97.89 & 2 & 0.0081 & $1.00 \mathrm{E}-12$ & 0 & 200.1 & 0.018 \\
\hline & DIVALIKE+J & -97.58 & 3 & 0.0074 & $1.00 \mathrm{E}-12$ & 0.0038 & 201.9 & 0.0075 \\
\hline & BAYAREALIKE & -113.8 & 2 & 0.011 & 0.08 & 0 & 231.9 & $2.20 \mathrm{E}-09$ \\
\hline & BAYAREALIKE+J & -106 & 3 & 0.0056 & 0.045 & 0.014 & 218.7 & $1.60 \mathrm{E}-06$ \\
\hline \multirow{6}{*}{$\begin{array}{l}\text { Pebas \& Acre } \\
\text { Systems (S1) }\end{array}$} & $\mathrm{DEC}$ & -95.45 & 2 & 0.0076 & $1.00 \mathrm{E}-12$ & 0 & 195.3 & 0.28 \\
\hline & $\mathrm{DEC}+\mathrm{J}$ & -93.39 & 3 & 0.0064 & $1.00 \mathrm{E}-12$ & 0.011 & 193.5 & 0.67 \\
\hline & DIVALIKE & -97.34 & 2 & 0.009 & $1.00 \mathrm{E}-12$ & 0 & 199 & 0.042 \\
\hline & DIVALIKE+J & -97.05 & 3 & 0.0083 & $1.00 \mathrm{E}-12$ & 0.0038 & 200.8 & 0.017 \\
\hline & BAYAREALIKE & -114.3 & 2 & 0.011 & 0.076 & 0 & 233 & $1.70 \mathrm{E}-09$ \\
\hline & BAYAREALIKE+J & -106.6 & 3 & 0.0068 & 0.047 & 0.013 & 219.9 & $1.20 \mathrm{E}-06$ \\
\hline \multirow{6}{*}{$\begin{array}{l}\text { Andes Old } \\
\text { uplift (S2) }\end{array}$} & DEC & -121.3 & 2 & 0.015 & 0.019 & 0 & 246.9 & 0.47 \\
\hline & $\mathrm{DEC}+\mathrm{J}$ & -120.4 & 3 & 0.013 & 0.018 & 0.0087 & 247.6 & 0.34 \\
\hline & DIVALIKE & -142.2 & 2 & 0.023 & 0.038 & 0 & 288.8 & $3.80 \mathrm{E}-10$ \\
\hline & DIVALIKE+J & -142.1 & 3 & 0.022 & 0.035 & 0.0056 & 290.9 & $1.30 \mathrm{E}-10$ \\
\hline & BAYAREALIKE & -126.2 & 2 & 0.017 & 0.093 & 0 & 256.7 & 0.0035 \\
\hline & BAYAREALIKE+J & -121.1 & 3 & 0.012 & 0.075 & 0.0097 & 248.8 & 0.18 \\
\hline \multirow{6}{*}{$\begin{array}{c}\text { Andes Young } \\
\text { uplift (S3) }\end{array}$} & $\mathrm{DEC}$ & -115.6 & 2 & 0.01 & 0.0092 & 0 & 235.6 & 0.45 \\
\hline & $\mathrm{DEC}+\mathrm{J}$ & -114.3 & 3 & 0.0091 & 0.0078 & 0.011 & 235.3 & 0.53 \\
\hline & DIVALIKE & -141.5 & 2 & 0.019 & 0.031 & 0 & 287.3 & $2.70 \mathrm{E}-12$ \\
\hline & DIVALIKE+J & -141.1 & 3 & 0.017 & 0.027 & 0.0092 & 289 & $1.20 \mathrm{E}-12$ \\
\hline & BAYAREALIKE & -122.8 & 2 & 0.013 & 0.087 & 0 & 249.9 & 0.0004 \\
\hline & BAYAREALIKE+J & -117.4 & 3 & 0.0089 & 0.07 & 0.0089 & 241.6 & 0.023 \\
\hline \multirow{6}{*}{$\begin{array}{l}\text { Pebas \& Andes } \\
\text { Old uplift (S4) }\end{array}$} & $\mathrm{DEC}$ & -120.9 & 2 & 0.015 & 0.012 & 0 & 246.2 & 0.56 \\
\hline & $\mathrm{DEC}+\mathbf{J}$ & -120.1 & 3 & 0.014 & 0.011 & 0.0087 & 246.8 & 0.42 \\
\hline & DIVALIKE & -143.2 & 2 & 0.024 & 0.029 & 0 & 290.8 & $1.20 \mathrm{E}-10$ \\
\hline & DIVALIKE+J & -143.1 & 3 & 0.023 & 0.027 & 0.0055 & 292.9 & $4.10 \mathrm{E}-11$ \\
\hline & BAYAREALIKE & -128.2 & 2 & 0.017 & 0.085 & 0 & 260.8 & 0.0004 \\
\hline & BAYAREALIKE+J & -123 & 3 & 0.012 & 0.072 & 0.01 & 252.6 & 0.023 \\
\hline \multirow{6}{*}{$\begin{array}{c}\text { Pebas \& } \\
\text { Young uplift } \\
\text { (S5) }\end{array}$} & $\mathrm{DEC}$ & -107.1 & 2 & 0.0093 & 0.007 & 0 & 218.6 & 0.27 \\
\hline & $\mathrm{DEC}+\mathrm{J}$ & -105 & 3 & 0.008 & 0.0059 & 0.016 & 216.6 & 0.73 \\
\hline & DIVALIKE & -135.4 & 2 & 0.014 & 0.018 & 0 & 275.2 & $1.40 \mathrm{E}-13$ \\
\hline & DIVALIKE+J & -134.7 & 3 & 0.013 & 0.014 & 0.011 & 276.2 & $8.60 \mathrm{E}-14$ \\
\hline & BAYAREALIKE & -120 & 2 & 0.013 & 0.085 & 0 & 244.3 & $7.30 \mathrm{E}-07$ \\
\hline & BAYAREALIKE+J & -114.5 & 3 & 0.0095 & 0.07 & 0.0091 & 235.8 & $5.10 \mathrm{E}-05$ \\
\hline
\end{tabular}




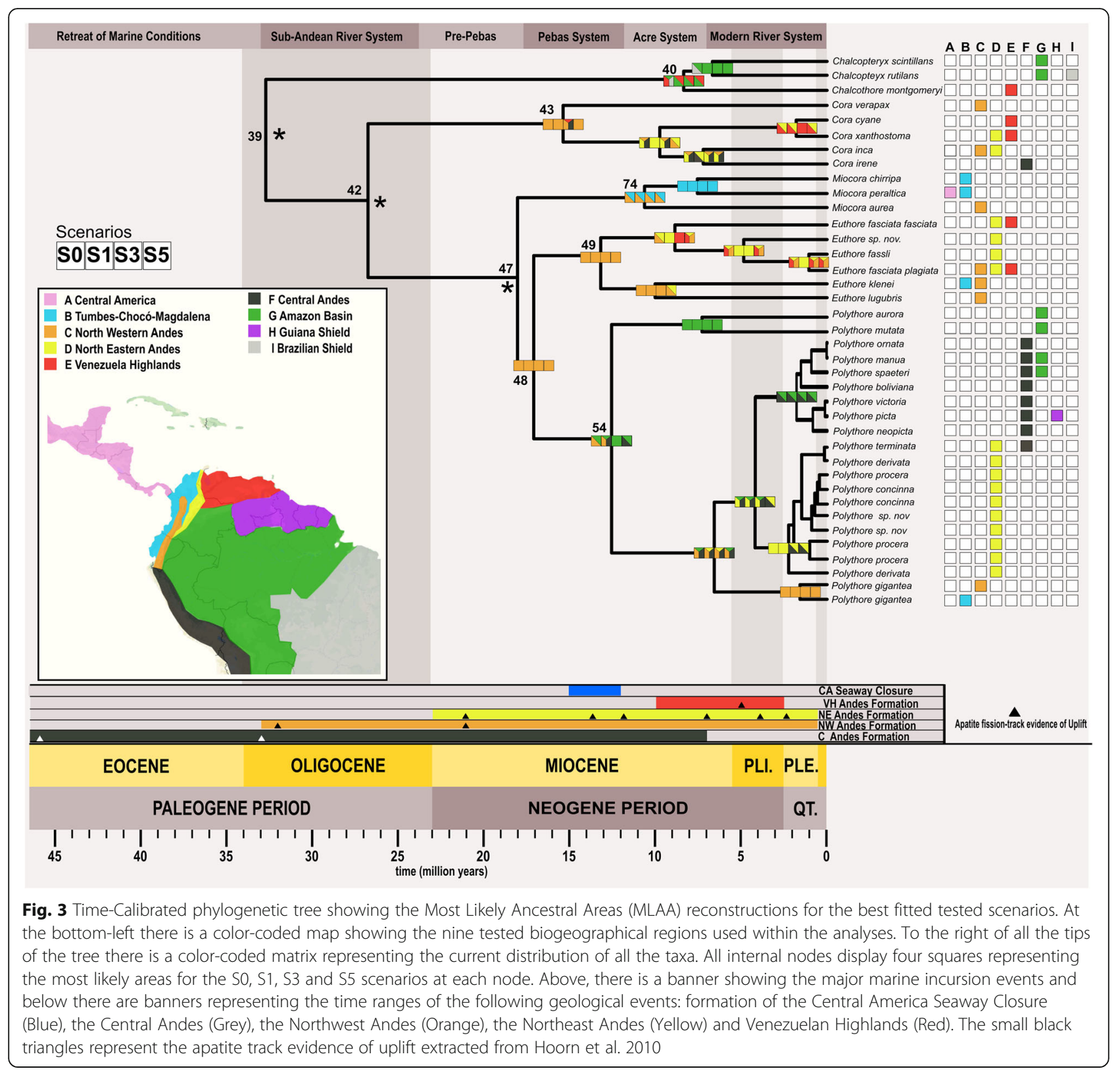

Clade in Polythore with the highest shift in the Eastern Clade (Fig. 4). When we observed the relative extinction $(\lambda / \mu)$ rate across the tree, we observed that this rate also decreases for this clade (Fig. 4). Our estimates show that the other clades within this family have a more constant diversification $(\lambda-\mu)$ and relative extinction $(\lambda / \mu)$ rates across the branches of the estimated tree.

\section{Discussion}

Overall, our phylogenetic reconstruction was consistent with that previously reported by Sanchez-Herrera [13], despite the 12 additional taxa; the same major clades were recovered with high supported values (Fig. 1, Fig. S1). Our time divergence results suggest that the Polythoridae
MRCA first appeared around the Eocene - Oligocene boundary, however most of the diversification within the family appeared during the mid-Miocene, Pliocene and Pleistocene epochs (Fig. 1). During these periods there were a few major geographical events occurring, including the uplift of different regions of the Andes, as well as the formation of the Pebas and Acre Systems [1, 18]. While the ancestral area for the MRCA of Polythoridae is uncertain, our biogeographical analyses suggest an origin-or at least early diversification-in the Northwestern Andes for most genera in Polythoridae, based on the ancestral areas of the different clades. Chalcopteryx-Chalcothore and Polythore are the only genera with a MRCA that may have had an Amazonian origin (Fig. 3, Table S2). 


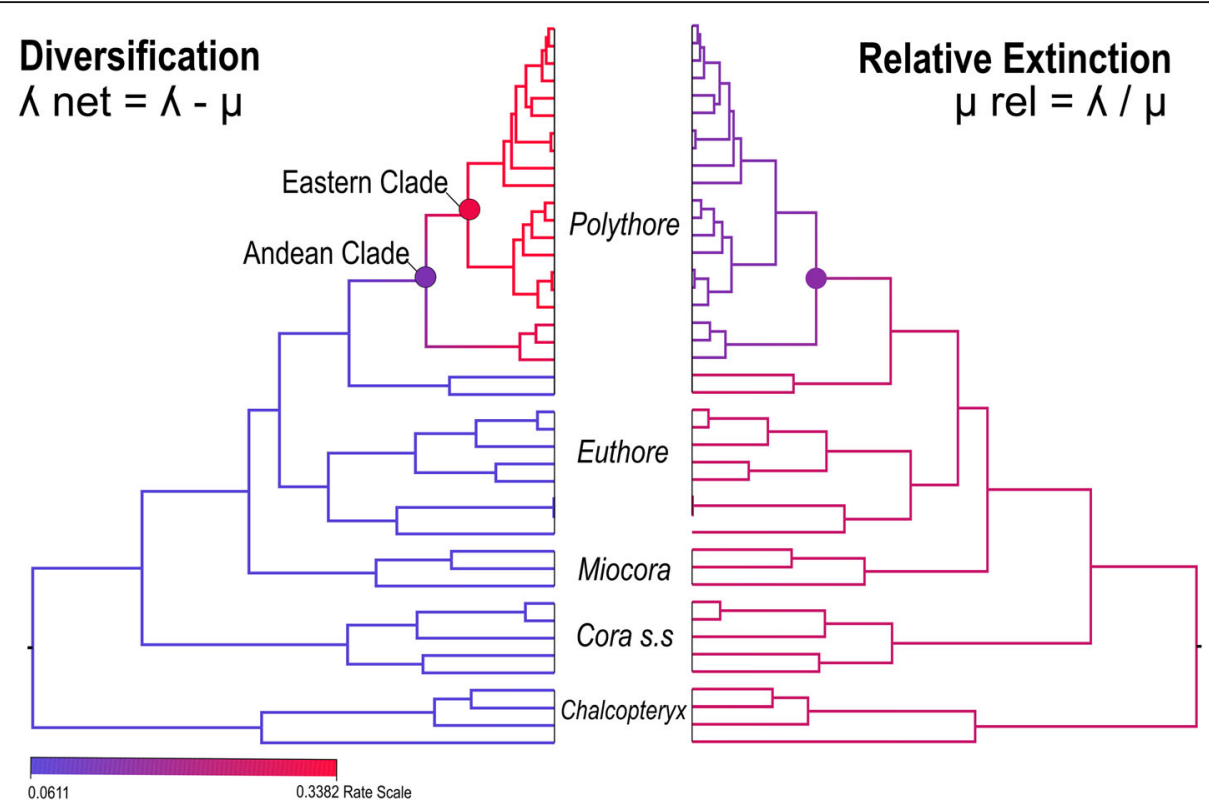

Fig. 4 Diversification and Extinction rate shifts within family Polythoridae obtained using the RevBayes Branch-Specific diversification model. To the left, the net diversification rate is represented, while to the right is the relative extinction rate

Our prediction that the uplift of the different regions of the Andes might be the driver of the diversification within Polythoridae was not completely supported by our results. Our biogeographical models found that the MRCA of most genera within Polythoridae seem to be better explained by the S1 model for the Pebas and Acre Systems (Table 1, Fig. 3). However, the Pebas and Acre Systems with the Young Andes uplift and the Old Andes uplift by itself (S5, S3) had a better fit (lower AICc) than the early uplift events of the Central Andes models (S2, S4). The latter may suggest that this event might be important to late diversification within the genera of this family. For example, the genus Polythore contains an Andean clade which shows a concordant pattern with the North Andes uplift. Likewise, Cora s.s, also shows a similar pattern separating two clades from the Northwest and Northeast Andes (Fig. 3) [11]. However, in terms of ancestral areas we found no significant differences across all the models we tested. Moreover, our results suggest that most of the diversification within Polythoridae is due to dispersal events rather than vicariance (Fig. S3). The distribution of those vicariance events (Fig. S3) in the time calibrated phylogeny is mainly within groups distributed along the Andes or that have representatives in Central America, reflecting the influence of these major geographical events on diversification.

What factors might be driving these biogeographical results? In particular for the family Polythoridae, the marine incursions and flooding events during the Miocene [19] likely had an effect on the distribution at the generic level. The Andes Cordillera seems to promote dispersal within the genera (Fig. 3, Fig. S3), and most likely these geological events have shaped the distribution of these damselflies, despite the mixed support of our models. These events may have cause significant changes in the biotic and abiotic conditions of different regions that may have induced Polythoridae damselfly dispersion to new suitable habitats. A previous assessment of Neotropical diversification for glass frogs (Allocentroleniae), an aquatic vertebrate, showed coincidental divergence time estimates with early uplifts of the Andes and lowland flooding events, similar to our results [6]. Moreover, our results suggest the Andes as a source of dispersal that did not play a role as a driver of diversification of lowland glass frog species [6]. We cannot deny that changes in the climatic conditions over that period of geological time may have had a strong influence on the biogeography of other organisms, including plants and herbivorous insects [20-22]. Our current analyses, which focused only on geological events, will not capture this complexity. Even though damselflies are generalist predators in both terrestrial and aquatic ecosystems, their distribution patterns might be affected by the vegetation and climatic barriers over evolutionary time.

A recent definition of the Neotropical forest relies on the combination of the following abiotic and biotic parameters: climate, floristic composition, vegetation structure and plant physiognomy [23]. Jaramillo [18] suggests that the formation of Neotropical terrestrial communities can be divided in two major phases, Cretaceous and Cenozoic, based on the defining parameters of Neotropical forests in these two geological eras. In our case the 
Cenozoic phase is more relevant, and it was characterized by the dominance of the flowering plants [24-27]. During the Neogene Period (i.e. Miocene and Pleistocene epochs), new biomes within the Neotropical regions flourished, such as savannas, dry forest, xerophytic forest, deserts, montane forest and paramos [18]. These biomes are determined by precipitation regimes rather than temperature [23]. However, questions regarding how climate and vegetation can influence the diversification of these damselflies remains untested.

We found multiple interchanges among the Amazon and Andean regions; many of them involved movement within and between the different ranges of the Andes, as well as movement into the Amazon, Guiana Shield, Venezuela Highlands, the Tumbes-Chocó-Magdalena Valley, and Central America (Fig. 3, Fig. S3). The different genera within Polythoridae showed an array of biogeographical patterns. The genus Polythore shows a pattern of dispersal from the Andean regions to the Amazon in some clades, as well as movement from the Northern to Central Andes (Fig. 3). On the other hand, Euthore moved from the Northwestern to Northeastern Andes and then to the Venezuelan highlands (Fig. 3). This genus is currently found at locations from 1000 to $2000 \mathrm{~m}$ in elevation; it is plausible that they colonized new habitats that became available during mountain building events in the Andes and Venezuelan highlands. Cora s.s and Miocora diversification was more likely driven by dispersal, as they cover a range of landscape types, and have moved across the Isthmus of Panama, the only groups in Polythoridae to do so. Interestingly, the age at which both of these genera diversified matches the age suggested by recent geological studies of the Central American Seaway closure during the middle of the Miocene $[2,28]$. This closure may also influence the ITCZ (Inter Tropical Convergence Zone) [29] that will have affected precipitation regimes in the Neotropical Region [30].

These damselflies are restricted to fast flowing forested streams and waterfalls in montane forests; these habitat requirements are likely a limiting factor to their distribution [31-33]. However, as general predators they are not limited by the distribution of food sources such as the host plant for phytophagous insects (e.g. Lepidoptera). The potential for dispersal in the immature stage is limited to drift, moving with the flow of creeks; dispersal by adults through flight offers a potential for greater movement but is still likely to be in proximity to the stream or creek. Distribution between watersheds is thus likely to be limited, which could explain the vicariance patterns observed in our results.

Our analyses suggest that Polythoridae has been diversifying through an episodic pattern (Table S4). Speciation $(\lambda)$ and net diversification $(\lambda-\mu)$ show an overall increase through time, while relative extinction $(\lambda / \mu)$ and extinction $(\mu)$ rates seem to remain somewhat constant through their evolutionary history. However, our branch-specific model of diversification shows a significant shift for the Andean Clade within the genus Polythore which might suggest that at least for this genus the intensified Andean uplift during the Pliocene has been promoting speciation (Fig. 3). The Andean uplift produced great modifications to the landscape; one of the major changes was in the flux of the hydrographic system towards the east, producing the actual Amazon and Orinoco basins. Furthermore, when the Andes reached their modern elevation by the end of the Miocene (i.e. 5-6 Ma) [1, 34-37], it generated two new biomes: cloud (montane) forest and paramo [18, 38]. The montane forest is the key habitat for the genus Polythore, and it has been suggested that the slopes of the Andes are an engine for speciation as the increase in topographic complexity generates diversity of microenvironments [1]. While all these species have relatively similar habitat requirements, they have generally disjunct distributions within the Andes, such that any local stream normally hosts only a single Polythore species, sometimes two species. The wing color diversity characteristic of Polythore is the highest within the Polythoridae--the central Andean Polythore have wings that include bands of black, orange and yellow patterns, while those of the Northeastern Andes have intense black and white patterning (except for P. concinna, which is orange). This color diversity also appears to be polymorphic within some of these clades [13, 14, 32]. Some of the color diversity could be explained by sexual selection, with local mate choices driving diverse color patterns in different regions $[39,40]$. Likewise, wing color may be under other constraints, such as thermal tolerance or selection by predators [41]. Having robust phylogenetic hypotheses will allow for further exploration of the reasons behind this radiation in Polythore, where population-level analysis will be a likely next step to disentangling the complex history of these striking creatures.

\section{Conclusions}

Our analyses suggest that the formation of the Pebas and Acre systems are associated with early diversification within the damselfly family Polythoridae. While our results indicate that the Andes were likely ancestral areas to many of the polythorid genera, the uplift of the Andes was not found to be strongly associated to tree topology, suggesting that dispersal to other regions (e.g. Amazon, Guiana Shield and Central America) played an important role in early diversification. Finally, the genus Polythore was the only one experiencing a significantly high rate of diversification, specifically within the Andean clade. This large-scale biogeographical analysis of a 
Neotropical damselfly family has yielded insights into speciation within this group and has suggested future research directions. Further exploration of the climatic and vegetation history of South and Central America in conjunction with population-level analyses may provide a better understanding of polythorid distribution than geological and geographical conditions alone.

\section{Methods}

\section{Taxon sampling}

A total of 48 of the 58 species of Polythoridae were included for all reconstructions presented here. All the taxa from Sanchez et al. 2018, including outgroups of other related Calopterygoid taxa (Calopterygidae, Philogangidae, Euphaeidae, and Pseudolestidae) and two nonCalopterygoidea from the Lestidae family (Lestes temporalis and Lestes dryas), are included within the analyses, with an additional 12 polythorid species new to these analyses. We included the monotypic Chalcothore montogomery De Marmels, 1988, 2 species of the 5 species of the genus Chalcopteryx, 6 of the 8 species of Cora s.s, 7 of the 20 species of the genus Euthore s.l., 3 of the 4 species of the Miocora genus, and 16 of the 21 species of the genus Polythore. Geographic origin, collector details, and Genbank Accession Numbers for all specimens are summarized in Table S6.

\section{DNA amplification, sequencing, and alignment}

For the 12 species new to this analysis we extracted DNA from either the legs or $1 / 4$ of the pterothorax using a DNeasy Tissue Kit (QIAGEN) from each specimen following the manufacturer's protocol. We amplified three mitochondrial and three nuclear fragments: Cytochrome Oxidase I ( $799 \mathrm{bp})$, NADH subunit I dehydrogenase ( $548 \mathrm{bp}), 16 \mathrm{~S},(\sim 340 \mathrm{bp}), 28 \mathrm{~S}(\sim 340 \mathrm{bp})$ and $18 \mathrm{~S}(\sim$ $600 \mathrm{bp}$ ) (see Table $\mathrm{S} 7$ for a list of primers used). All gene fragments were amplified using PCR conditions as described in the associated publications for each pair of primers (Table S7) Macrogen USA Inc. laboratories (NY) performed the purification protocol for the PCR products $(15 \mu \mathrm{l}$ final volume for each primer) and the Sanger DNA sequencing. Primer contig assembly, peak chromatogram verification and the generation of perindividual consensus sequences were done using Geneious v8 [42]. All fragments were aligned using MAFFT [43] and then manually aligned in Mesquite [44]. Ribosomal genes were aligned manually with reference to secondary structure using the methods described in Kjer [45] and Kjer et al. [46]. Finally, all genes were concatenated using Mesquite for the overall analyses. We reconstructed a mid-root phylogenetic hypothesis using a Maximum Likelihood criterium in IQTree [47] including the 12 new species included within this analysis; both support values, SH-aLRT and UFBootstraps, were estimated for each node.

\section{Time divergence analysis}

A relaxed-clock molecular dating analysis on the partitioned dataset was run using BEAST v 1.8.4 [48]. Specifically, we partitioned the gene fragments as follows: (i) We linked the sites and clock models for all mtDNA fragments and (ii) unlinked all nuclear ones from their clock and site models. We implemented the appropriate model selection for each partition: JC for $18 \mathrm{~S}$ and $28 \mathrm{~S}$ nDNA, we set the model to GTR + G, models obtained using the model selection tool of IQTree for ND1, 16S and COI [47]. We used lognormal relaxed clock models for all partitions, under a Yule speciation model tree prior. We estimated an unrooted topology to avoid biased node age estimation, all posterior probabilities (PP) for the nodes were estimated. Most of the fossil calibrations prior distributions were uniform considering the oldest fossil age as the maximum and the youngest fossil age as the minimum bound. For the Euphaedidae outgroup calibration we created a Lognormal distribution of all the fossil ages that accounted for all the age variation. Table 2 shows the calibrated nodes (4), stem fossils (10) and prior distributions selected for the analyses. We ran four independent analyses to ensure convergence of the $\mathrm{MCMC}$; convergence was checked using Tracer 1.7 [49]. Finally, the independent runs for each treatment were combined using LogCombiner $\mathrm{v}$ 1.8.3 [48]. The dated ultrametric tree was obtained using TreeAnnotator v 1.8.3 [48] and visualized using Figtree v 1.4 (http://tree.bio.ed.ac.uk/software/figtree/) and the $\mathrm{R}$ package ggtree [50].

\section{Biogeographical reconstructions}

The ancestral range estimation was performed with the following software: $\mathrm{R}$ package Biogeobears v.0.2.1 [51] and RASP (Reconstruct Ancestral State in Phylogenies) [52]. Both software packages allowed us to customize dispersal rates matrices and time stratification events, as well as infer areas among the following historical biogeography frameworks: Dispersal-Vicariance Analysis (DIVA [53]), Statistical Dispersal-Vicariance (S-DIVA [54]), Dispersal-Extinction Cladogenesis (DEC [55]), and Bayesian inference of historical biogeography for discrete areas (BayArea [56]). In addition, Matzke [57] included a new parameter in all the models accounting for what he calls the founder-event speciation. These are described as "jumping dispersal events (J)", which are rare events that occur when a new population colonizes a new area [57]. In particular, BioGeoBEARS has implemented model selection among six different historical biogeographic scenarios (DEC, DEC + J, DIVALIKE, DIVALIKE + J, BayArea, BayArea + J [51];). Although, Ree and Sanmartín [15] recently highlighted there are conceptual and statistical issues with the DEC + J model implemented in BioGeoBEARS, which can sometimes favor 
Table 2 Fossils supporting each of the node calibrations and the prior distributions selected for the Bayesian time divergence analysis. Node numbers are depicted in Fig. 1

\begin{tabular}{|c|c|c|c|}
\hline Node/TAXA & Fossil Classification and estimated ages & $\begin{array}{l}\text { Type Locality/ } \\
\text { PaleoDB }\end{array}$ & Prior distribution \\
\hline Root & $\begin{array}{l}\text { Odonata, Zygoptera, Eosagrionidae, Eosagrion risi †, Early Jurassic, Toarcian, 183-182 } \\
\text { Ma (Handlirsch, 1920) }\end{array}$ & $\begin{array}{l}\text { Germany/ } \\
\text { Dobbertin, } \\
\text { Mecklenburg } \\
\text { PaleoDB 123,987 }\end{array}$ & $\begin{array}{l}\text { Uniform prior } \\
\text { distribution } \max = \\
\mathbf{1 8 3} \\
\min =\mathbf{4 7 . 8}\end{array}$ \\
\hline Calopterygoidea & $\begin{array}{l}\text { Odonata, Zygoptera, Calopterygoidea, Calopterygidae Sinocalopteryx shanyongensis t, } \\
\text { Eocene, Ypresian (56-47.8 Ma) NIGP } 151367 \text { (Lin et al., 2010) } \\
\text { Odonata, Zygoptera, Epallagidae, Labandeiraia europae t, Eocene, Ypresian (56-47.8 } \\
\text { Ma) } \\
\text { Odonata, Zygoptera, Epallagidae, Ejerslevia haraldi t, Eocene, Ypresian (56-47.8 Ma) } \\
\text { (Zessin, 2011) }\end{array}$ & $\begin{array}{l}\text { Yunnan, China } \\
\text { PaleoDB 113,892 } \\
\text { Island of Fur, } \\
\text { Denmark } \\
\text { PaleoDB 123,998, } \\
127,173 \\
\text { Ejerslev, Mors, } \\
\text { Denmark } \\
\text { PaleoDB 157,041 }\end{array}$ & \\
\hline $\begin{array}{l}\text { Outgroup } \\
\text { Euphaeidae }\end{array}$ & $\begin{array}{l}\text { Odonata, Zygoptera, Epallagidae, Labandeiraia americaborealis t, Eocene, Bridgerian } \\
\text { (50-46.2 Ma) 31.665A-B (Petrulevicius et al., 2007) } \\
\text { Odonata, Zygoptera, Epallagidae, Litheuphaea coloradensis t, Eocene, Bridgerian (50- } \\
46.2 \mathrm{Ma} \text { ) BMNH PI II } 562 \text { (Petrulevicius et al., 2007) } \\
\text { Odonata, Zygoptera, Epallagidae, Eodichroma mirifica t, Late/Upper Eocene, (37.2- } \\
\text { 33.9) } \\
\text { (Cockerell 1923) } \\
\text { Odonata, Zygoptera, Epallagidae, Litheuphaea ludwigi t, Eocene, Priabonian (38-33.9 } \\
\text { Ma) (Bechly,1990) } \\
\text { Odonata, Zygoptera, Epallagidae, Elektroeuphaea flecki t, Eocene, Priabonian (38-33.9 } \\
\text { Ma) (Nel et al., 2013) } \\
\text { Odonata, Zygoptera, Epallagidae, Parazacallites aquisextanea t, Oligocene, Chattian } \\
\text { (28.1-23.03 Ma) MNHN IPM-R.06688 (Nel, 1988) }\end{array}$ & $\begin{array}{l}\text { Colorado, USA } \\
\text { PaleoDB = 107,337 } \\
\text { Colorado, USA } \\
\text { PaleoDB }=107,337 \\
\text { Texas, USA } \\
\text { PaleoDB }=130,390 \\
\text { Baltic Amber, } \\
\text { Russian Federation } \\
\text { PaleoDB = 123,911 } \\
\text { Baltic Amber, } \\
\text { Poland } \\
\text { PaleoDB }=123,215 \\
\text { Bouches-Du-Rhone, } \\
\text { France } \\
\text { PaleoDB 123,943 }\end{array}$ & $\begin{array}{l}\text { LogNormal; mean = } \\
\text { 50; std. }=0.15\end{array}$ \\
\hline $\begin{array}{l}\text { Ingroup/ } \\
\text { Polythoridae }\end{array}$ & $\begin{array}{l}\text { Odonata, Zygoptera, Polythoroidea, Bolcathore colorata t, Eocene, Lutetian (47.8-41.3 } \\
\text { Ma) MCSNV I.G. 37,582 (Gentilini, 2002) } \\
\text { Odonata, Zygoptera, } \\
\text { Polythoroidea, Bolcathore sp. t, Eocene, Priabonian (38-33.9 Ma) MCSNV I.G. 37,582 } \\
\text { (Nel and Fleck, 2014) } \\
\text { Odonata, Zygoptera, Protothore explicata t, Eocene, Bartonian (41.3-38 Ma) (Cockrell, } \\
\text { 1930) }\end{array}$ & $\begin{array}{l}\text { Pesciara di Bolca, } \\
\text { Italy } \\
\text { PaleoDB }=122,230 \\
\text { Isle of Wight, United } \\
\text { Kingdom } \\
\text { PaleoDB }=123,960 \\
\text { California, USA } \\
\text { PaleoDB }=117,537\end{array}$ & $\begin{array}{l}\text { Uniform prior } \\
\text { distribution } \max =\mathbf{4 8} \\
\min =\mathbf{3 3 . 9}\end{array}$ \\
\hline
\end{tabular}

unparsimonious numbers for "jumping dispersal events"; and as a result it will not reflect a more close approximation of the "true" model of range evolution. For our analyses, we designated nine distinct geological areas based on the geological literature [1, 34, 35], which include; (A) Central America, (B) Tumbes-ChocoMagdalena, (C) North Western Andes, (D) North Eastern Andes, (E) Venezuela Highlands, (F) Central Andes, (G) Amazon Basin, (H) Guiana Shield, and (I) Brazilian Shield (Fig. 3, Table S2). The extant species distributions for each of our species at the tips of our time calibrated tree (Fig. 3) were compiled from our locality data, and specimen records information from the following collections: Florida State Arthropod Collection (FSCA), U.S National Entomological Collection (USNM), Andes $\mathrm{Mu}-$ seum of Natural History (ANDES), Entomological Collection of the Universidad de Antioquia, Colombia (CEUA), and the Rutgers Newark Entomological Collection (RUN_ODO). Ranges were restricted to be comprised of at most three different areas as there are no extant species that occupy a range made up of more than three of the determined areas. Impossible adjacency range combinations were manually removed from the ranges list used by BioGeoBEARS during the inference of ancestral states. Details on the model parameters, areas allowed, dispersal probabilities and time stratification schemes for each of the all five scenarios (S0-S5) are explained in Fig. 2. All these scenarios were based on a combination of the most recent reviews concerning the Amazon Basin Formation, Miocene flooding events and Andean uplift history $[1,19,35]$. Each of these scenarios were subject to the six available historical biogeographic models of BioGeoBEARS, from the best-fit model based on the corrected Akaike Information Criterion $(\mathrm{AICc})$ weights. However, following the recommendations of Ree and Sanmartín [15] we assessed model consistency by comparing among the selected BioGeoBEARS models and carefully examined the reconstructions performed for those models in both BioGeoBEARS and RASP. Afterwards, we favored the 
model based on best fit for the empirical information on Polythoridae and method consistency. The best selected reconstructed areas models, for each scenario were mapped over the best time calibrated phylogeny and the directionality of the dispersal and vicariance events was represented in the nodes for each major supported clade $[51,57]$.

\section{Time diversification analyses}

To investigate the patterns of diversification and extinction rate variation through time and across lineages, we chose RevBayes [16, 17] to test the best diversification models and rate shifts, due to the high uncertainty associated with phylogenetic tree estimation. We calculated the Bayes Factors [58] for each pair of candidate models estimating the marginal Likelihood ( $\mathrm{mlnL}$ ) using two sampling algorithms (stepping-stone sampling [59] and path-sampling [60]) among the following models: Yule Pure-Birth Model, Birth-Death Constant Model and Episodic Birth-Death Models with multiple time intervals $(4,10$ and 100 [61]). Once the best model through time was selected we calculated the speciation $(\lambda)$, extinction $(\mu)$, net diversification $(\lambda-\mu)$ and relative extinction $(\lambda / \mu)$ for the best model; all plots were generated using the RevGadgets package in R [62]. In addition, we used the Branch Specific Diversification Model implemented in RevBayes $[16,17]$ to detect rate shifts across lineages. For all the models implemented in RevBayes [16] we assumed a uniform taxon sampling and an incomplete sampling fraction of $48 / 57$. For the model selection, we ran a total of 5000 MCMC generations with a burnin of 1000 generations, all the parameter outputs were checked in Tracer [49] to assess the ESS, prior and posterior probability, and markov chain proper behavior. We estimated the mlnL of the models sampling the power posterior of each model for 1000 MCMC generations with a burnin of $10 \%$. For the branch specific estimation, we assumed the heterogeneous model and we test several rate categories $(N=1$ (constant), 4 and 10) across the lineages, for each rate we obtained the marginal probabilities and Bayes Factors as explained above. For the best selected model, we wrote a file with all the estimated parameters $(\lambda$ avg., $\mu$ avg., $\lambda-\mu$ avg., $\lambda / \mu$ avg. and its $95 \%$ confidence ranges) for each branch that can be mapped over our BEAST time divergence tree and was visualized using FigTree (http:// tree.bio.ed.ac.uk/software/figtree/).

\section{Supplementary information}

Supplementary information accompanies this paper at https://doi.org/10. 1186/s12862-020-01638-z.

Additional file 1: Fig. S1. A. Best ML IQTree phylogenetic reconstruction for the family Polythoridae. UFBoostraps $(10,000$ pseudoreplicates) and SH-aLRT (1000) branch supports are above each branch. B. Geographic distribution of the family Polythoridae.
Additional file 2: Table S2. Most likely estimated ancestral areas for the main nodes within the Polythoridae family. The best biogeographical models for all scenarios (S0-S5), using both BioGeoBEARS (grey columns) and RASP (white columns) reconstruction methods, are shown. The designated areas include; (A) Central America, (B) Tumbes-ChocoMagdalena, (C) North Western Andes, (D) North Eastern Andes, (E) Venezuela Highlands, (F) Central Andes, (G) Amazon Basin, (H) Guiana Shield, and (I) Brazilian Shield. * indicates high uncertainty values for these nodes' numbers correspond to Fig. 3.

Additional file 3: Fig. S3. Time-calibrated tree highlighting the nodes with dispersal (green), vicariance (blue) and extinction (red) events implemented in the S-DEC model for the Pebas and Acre systems (S1) scenario.

Additional file 4: Table S4. Multiple comparisons of the Bayes Factors and marginal likelihoods for all the diversification models tested (Yule, Birth-Death (BD), Episodic Birth-Death (EBD); the latter with multiple episodes 4,10 or 20)

Additional file 5: Fig. S5. Net diversification, relative extinction, speciation and extinction rates inferred from the best diversification model (EBDN20) implemented in RevBayes.

Additional file 6: Table S6. Taxon Sampling, Accession numbers and Geographic location.

Additional file 7: Table S7. PCR conditions and Primers used in this analysis.

\section{Abbreviations}

MCRA: Most Common Recent Ancestor; RASP: Reconstruct Ancestral State in Phylogenies; ANDES: Andean uplift; ANDES O: Old Andean uplift; ANDES Y: Young Andean uplift; P\&AS: Pebas and Acre Systems; P\&OA: Pebas and Old Andes; P\&YA: Pebas and Young Andes

\section{Acknowledgements}

We are grateful to Adolfo Cordero, Joachim Hoffman, Juan Grados and Andrea Encalada for their support during fieldwork collection and permit solicitation. Special thanks to the Tiputini Research Station, Los Cedros Reserve and Pampa Hermosa Lodge for their hospitality. Thanks to Emilio Realpe, Cornelio Bota, Rosser Garrison, Natalia von Ellenrieder, Bill Mauffray and Ken Tennessen for allowing access to their personal collections, the Florida State Arthropod Collection, Museo ANDES, Universidad de Antioquia Entomology Collection. We would also like to give a special thank you to the following Rutgers-Newark undergraduate students who helped with the molecular bench work: Daniel Troast, Gabby Hanna, Meriem Hanna, Adriana Morocho and Nevin Mathews. We acknowledge the Ministerio de Agricultura de Peru and the Autoridad Nacional de Licencias ambientales de Colombia (ANLA permit 530) and Ecuador for allowing the specimen collection.

\section{Authors' contributions}

MSH performed field collection, lab work and analyses and drafted the manuscript. CDB performed field collection and manuscript drafting. RN performed analysis and drafted components of the manuscript. CS and JW contributed to manuscript preparation. All authors have read and approved the manuscript.

\section{Funding}

Funding for this work was provided in part through: the National Geographic Society Waitt Explorer Grant W265-13 awarded to MS for fieldwork specimen collection expeditions, and by startup funds of JW through Rutgers-Newark, CS and MS by the Patrimonio Fondo Nacional de Financiamiento para la Ciencia, Tecnología y la Innovación Francisco José de Caldas (COLCIENCIAS) number FP448442-072-2016 for molecular data collection benchwork.

\section{Availability of data and materials}

Data are available in GenBank; see Supplementary Table S6 for accession numbers.

All files for Time Divergence analyses and Biogeographical Reconstructions are published in the following repository: https://doi.org/10.5281/zenodo. 3862741 


\section{Ethics approval and consent to participate}

Not Applicable.

\section{Consent for publication}

All authors have read and approved the manuscript.

\section{Competing interests}

The author(s) declare no competing interests.

\section{Author details}

'Department of Biology, Faculty of Natural Sciences, Universidad del Rosario, Bogota, DC, Colombia. ${ }^{2}$ Federated Department of Biological Sciences. Rutgers, The State University of New Jersey, Newark, NJ, USA. ${ }^{3}$ Department of Ecology \& Evolutionary Biology, Cornell University, Ithaca, NY, USA. ${ }^{4}$ Departament of Biology, The City University of New York, New York, NY, USA. ${ }^{5}$ American Museum of Natural History, New York, NY, USA

Received: 17 December 2019 Accepted: 15 June 2020 Published online: 24 June 2020

\section{References}

1. Hoorn C, Wesselingh FP, ter Steege H, Bermudez MA, Mora A, Sevink J, et al. Amazonia through time: Andean uplift, climate change, landscape evolution, and biodiversity. Science. 2010;330:927-31.

2. Montes C, Cardona A, Jaramillo C, Pardo A, Silva JC, Valencia V, et al. Middle Miocene closure of the central American seaway. Science. 2015;348:226-9.

3. Potter PE, Szatmari P. Global Miocene tectonics and the modern world. Earth-Sci Rev. 2009;96:279-95.

4. Jaramillo CA. Evolution of the isthmus of Panama: biological, Paleoceanographic and Paleoclimatological Implications. John Wiley \& Sons; 2018. http://repository.si.edu//handle/10088/35473. Accessed 15 Nov 2019.

5. Santos JC, Coloma LA, Summers K, Caldwell JP, Ree R, Cannatella DC. Amazonian amphibian diversity is primarily derived from late Miocene Andean lineages. PLoS Biol. 2009;7:e56.

6. Castroviejo-Fisher S, Guayasamin JM, Gonzalez-Voyer A, Vilà C. Neotropical diversification seen through glassfrogs. J Biogeogr. 2014;41:66-80.

7. Lisa De-Silva D, Mota LL, Chazot N, Mallarino R, Silva-Brandão KL, Piñerez $L M G$, et al. North Andean origin and diversification of the largest ithomiine butterfly genus. Sci Rep. 2017;7:45966.

8. Chazot N, De-Silva DL, Willmott KR, Freitas AVL, Lamas G, Mallet J, et al. Contrasting patterns of Andean diversification among three diverse clades of Neotropical clearwing butterflies. Ecol Evol. 2018;8:3965-82.

9. Contreras-Ortiz N, Atchison GW, Hughes CE, Madriňán S. Convergent evolution of high elevation plant growth forms and geographically structured variation in Andean Lupinus (Fabaceae). Bot J Linn Soc. 2018;187: $118-36$

10. Hazzi NA, Moreno JS, Ortiz-Movliav C, Palacio RD. Biogeographic regions and events of isolation and diversification of the endemic biota of the tropical Andes. Proc Natl Acad Sci U S A. 2018;115:7985-90.

11. Weissing FJ, Edelaar P, van Doorn GS. Adaptive speciation theory: a conceptual review. Behav Ecol Sociobiol. 2011;65:461-80.

12. Garrison RW, von Ellenrieder N, Louton JA. Damselfly genera of the New World: an illustrated and annotated key to the Zygoptera. Baltimore: Johns Hopkins University Press; 2010

13. Sanchez Herrera M, Beatty C, Nunes R, Realpe E, Salazar C, Ware JL. A molecular systematic analysis of the Neotropical banner winged damselflies (Polythoridae: Odonata): phylogenetic relationships of Polythoridae. Syst Entomol. 2018:43:56-67.

14. Sánchez Herrera M, Kuhn WR, Lorenzo-Carballa MO, Harding KM, Ankrom N, Sherratt TN, et al. Mixed signals? Morphological and molecular evidence suggest a color polymorphism in some neotropical polythore damselflies. PLoS One. 2015;10:e0125074.

15. Ree RH, Sanmartín I. Conceptual and statistical problems with the DEC+J model of founder-event speciation and its comparison with DEC via model selection. J Biogeogr. 2018;45:741-9.

16. Höhna S, Landis MJ, Heath TA, Boussau B, Lartillot N, Moore BR, et al. RevBayes: Bayesian phylogenetic inference using graphical models and an interactive model-specification language. Syst Biol. 2016;65:726-36.

17. Höhna S. The time-dependent reconstructed evolutionary process with a key-role for mass-extinction events. J Theor Biol. 2015;380:321-31.
18. Jaramillo C. 140 million years of tropical biome evolution. In: Libro Geología de Colombia. In: Gómez, J. \& Pinilla-Pachon, A.O. (editors). Bogotá: Servicio Geológico Colombiano, Publicaciones Geológicas Especiales; 2019. p. 28. https://doi.org/10.32685/pub.esp.36.2019.06. Accessed 14 Nov 2019.

19. Jaramillo C, Romero I, D'Apolito C, Bayona G, Duarte E, Louwye S, et al. Miocene flooding events of western Amazonia. Sci Adv. 2017;3:e1601693.

20. Ramírez SR, Gravendeel B, Singer RB, Marshall CR, Pierce NE. Dating the origin of the Orchidaceae from a fossil orchid with its pollinator. Nature. 2007:448:1042-5.

21. Schuettpelz E, Pryer KM. Evidence for a Cenozoic radiation of ferns in an angiosperm-dominated canopy. PNAS. 2009;106:11200-5.

22. Schultz TR, Brady SG. Major evolutionary transitions in ant agriculture. Proc Natl Acad Sci. 2008:105:5435-40.

23. Jaramillo C, Cárdenas A. Global warming and Neotropical rainforests: a historical perspective. Annu Rev Earth Planet Sci. 2013:41:741-66.

24. Wang H, Moore MJ, Soltis PS, Bell CD, Brockington SF, Alexandre R, et al. Rosid radiation and the rapid rise of angiosperm-dominated forests. PNAS. 2009;106:3853-8.

25. Davis CC, Webb CO, Wurdack KJ, Jaramillo CA, Donoghue MJ. Explosive radiation of Malpighiales supports a mid-cretaceous origin of modern tropical rain forests. Am Nat. 2005;165:E36-65.

26. Pardo-Trujillo A, Jaramillo CA, Oboh-lkuenobe FE. Paleogene palynostratigraphy of the eastern middle Magdalena Valley, Colombia. Palynology. 2003;27:155-78.

27. Hammen TVD. Estratigrafía del terciario y maestrichtiano con continentales y tectogénesis de los Andes colombianos. 1. 1958;6:60-116.

28. Bacon CD, Silvestro D, Jaramillo C, Smith BT, Chakrabarty P, Antonelli A. Reply to Lessios and Marko et al.: early and progressive migration across the isthmus of Panama is robust to missing data and biases: fig. 1. Proc Natl Acad Sci U S A. 2015:112:E5767-8.

29. Poveda G, Waylen PR, Pulwarty RS. Annual and inter-annual variability of the present climate in northern South America and southern Mesoamerica. Palaeogeogr Palaeoclimatol Palaeoecol. 2006;234:3-27.

30. Chiang JCH, Bitz CM. Influence of high latitude ice cover on the marine Intertropical convergence zone. Clim Dyn. 2005;25:477-96.

31. Cordero-Rivera A, Sanmartín-Villar I, Sánchez Herrera M, Rivas-Torres A, Encalada AC. Survival and longevity in neotropical damselflies (Odonata, Polythoridae). Anim Biodiv Conserv. 2019;:293-300.

32. Sanmartín-Villar I, Cordero-Rivera A. Female colour polymorphism and unique reproductive behaviour in Polythore damselflies (Zygoptera: Polythoridae). Neotrop Entomol. 2016;45:658-64.

33. Sánchez-Herrera M, Realpe E. Population structure of Polythore procera at a Colombian stream (Odonata: Polythoridae). Int J Odonatol. 2010;13:27-37.

34. Garzione CN, Auerbach DJ, Jin-Sook Smith J, Rosario JJ, Passey BH, Jordan $T E$, et al. Clumped isotope evidence for diachronous surface cooling of the Altiplano and pulsed surface uplift of the Central Andes. Earth Planet Sci Lett. 2014:393:173-81.

35. Gregory-Wodzicki KM. Uplift history of the central and northern Andes: a review. Geol Soc Am Bull. 2000;112:1091-105.

36. Kar N, Garzione CN, Jaramillo C, Shanahan T, Carlotto V, Pullen A, et al. Rapid regional surface uplift of the northern Altiplano plateau revealed by multiproxy paleoclimate reconstruction. Earth Planet Sci Lett. 2016;447:33-47.

37. Ghosh P, Garzione CN, Eiler JM. Rapid uplift of the Altiplano revealed through 13C-180 bonds in Paleosol carbonates. Science. 2006;311:511-5.

38. Wallis GP, Waters JM, Upton P, Craw D. Transverse Alpine speciation driven by glaciation. Trends Ecol Evol. 2016;31:916-26.

39. Kronforst MR, Young LG, Kapan DD, McNeely C, O'Neill RJ, Gilbert LE. Linkage of butterfly mate preference and wing color preference cue at the genomic location of wingless. Proc Natl Acad Sci U S A. 2006;103:6575-80.

40. Cooper IA. Ecology of sexual dimorphism and clinal variation of coloration in a damselfly. Am Nat. 2010;176:566-72.

41. Moore MP, Lis C, Gherghel I, Martin RA. Temperature shapes the costs, benefits and geographic diversification of sexual coloration in a dragonfly. Ecol Lett. 2019;22:437-46.

42. Kearse M, Moir R, Wilson A, Stones-Havas S, Cheung M, Sturrock S, et al. Geneious basic: an integrated and extendable desktop software platform for the organization and analysis of sequence data. Bioinformatics. 2012;28:1647-9.

43. Katoh K, Standley DM. MAFFT multiple sequence alignment software version 7: improvements in performance and usability. Mol Biol Evol. 2013;30:772-80.

44. Maddison WP, Maddison DR. Mesquite: a modular system for evolutionary analysis; 2018 
45. Kjer KM. Use of rRNA secondary structure in phylogenetic studies to identify homologous positions: an example of alignment and data presentation from the frogs. Mol Phylogenet Evol. 1995;4:314-30.

46. Kjer KM, Honeycutt RL. Site specific rates of mitochondrial genomes and the phylogeny of eutheria. BMC Evol Biol. 2007;7:8.

47. Nguyen L-T, Schmidt HA, von Haeseler A, Minh BQ. IQ-TREE: a fast and effective stochastic algorithm for estimating maximum-likelihood phylogenies. Mol Biol Evol. 2015;32:268-74.

48. Drummond AJ, Suchard MA, Xie D, Rambaut A. Bayesian phylogenetics with BEAUti and the BEAST 1.7. Mol Biol Evol. 2012;29:1969-73.

49. Rambaut A, Drummond AJ, Xie D, Baele G, Suchard MA. Posterior Summarization in Bayesian Phylogenetics Using Tracer 1.7. Syst Biol. 2018; 67(5):901-4, https://doi.org/10.1093/sysbio/syy032.

50. Yu G, Smith DK, Zhu H, Guan Y, Lam TT-Y ggtree : an r package for visualization and annotation of phylogenetic trees with their covariates and other associated data Methods Ecol Evol. 2017;8:28-36.

51. Matzke NJ. Probabilistic historical biogeography: new models for founderevent speciation, imperfect detection, and fossils allow improved accuracy and model-testing; 2013

52. Yu Y, Harris AJ, Blair C, He X. RASP (reconstruct ancestral state in phylogenies): a tool for historical biogeography. Mol Phylogenet Evol. 2015; 87:46-9.

53. Ronquist F. Dispersal-Vicariance analysis: a new approach to the quantification of historical biogeography. Syst Biol. 1997:46:195-203.

54. Yu Y, Harris AJ, He X. S-DIVA (statistical dispersal-Vicariance analysis): a tool for inferring biogeographic histories. Mol Phylogenet Evol. 2010;56:848-50.

55. Ree RH, Smith SA. Maximum likelihood inference of geographic range evolution by dispersal, local extinction, and cladogenesis. Syst Biol. 2008:57:4-14.

56. Landis MJ, Matzke NJ, Moore BR, Huelsenbeck JP. Bayesian analysis of biogeography when the number of areas is large. Syst Biol. 2013;62:789-804.

57. Matzke NJ. Model selection in historical biogeography reveals that founderevent speciation is a crucial process in island clades. Syst Biol. 2014;63:951-70.

58. Kass RE, Raftery AE. Bayes factors. J Am Stat Assoc. 1995;90:773-95.

59. Xie W, Lewis PO, Fan Y, Kuo L, Chen M-H. Improving marginal likelihood estimation for Bayesian phylogenetic model selection. Syst Biol. 2011;60: $150-60$.

60. Lartillot N, Philippe H. Computing Bayes factors using thermodynamic integration. Syst Biol. 2006;55:195-207.

61. May MR, Höhna S, Moore BR. A Bayesian approach for detecting the impact of mass-extinction events on molecular phylogenies when rates of lineage diversification may vary. Methods Ecol Evol. 2016;7:947-59.

62. Höhna S, Heath TA, Boussau B, Landis MJ, Ronquist F, Huelsenbeck JP. Probabilistic graphical model representation in phylogenetics. Syst Biol. 2014;63:753-71.

\section{Publisher's Note}

Springer Nature remains neutral with regard to jurisdictional claims in published maps and institutional affiliations.

Ready to submit your research? Choose BMC and benefit from:

- fast, convenient online submission

- thorough peer review by experienced researchers in your field

- rapid publication on acceptance

- support for research data, including large and complex data types

- gold Open Access which fosters wider collaboration and increased citations

- maximum visibility for your research: over $100 \mathrm{M}$ website views per year

At $\mathrm{BMC}$, research is always in progress.

Learn more biomedcentral.com/submissions 